\title{
МЕЖДУНАРОДНО-ПРАВОВЫЕ И ПОЛИТИЧЕСКИЕ ПОСЛЕДСТВИЯ ИНТЕРНИРОВАНИЯ ЯПОНСКИХ ВОЕННОПЛЕННЫХ НА ДАЛЬНЕМ ВОСТОКЕ СССР (СЕНТЯБРЬ 1945-1956)
}

\begin{abstract}
Аннотация: Предметом изучения является режим военного плена и взаимоотношения японских военнопленных с властными структурами в СССР в период с сентября 1945-декабря 1956 г2., которым после Второй мировой войны подверглись бывшие военнослужащце Квантунской армии. Пребывание японских военнопленных на Дальнем Востоке СССР в исследуемый период составляет одно из важнейших граней комплексного изучения проблемы иностранных военнопленных на Дальнем Востоке России в ХХ в. Обращение к данной теме в годовщину 70-летия Победы СССР над милитаристской Японией подкреплено введением новых документов и материалов по данной теме, раннее не доступных исследователям. Методологической основой являются международно-правовые аспекты военного плена, теоретические основы его современного состояния, с помощью которых выявляются различные стороны функиионирования плена. Научная новизна обусловлена системным исследованием проблемы военнопленных на Дальнем Востоке СССР, а также заключена во введении новых документов и материалов по данной теме. Впервые прослежены международно-правовые аспекты военного плена на Дальнем Востоке, определены особенности политики СССР по отнотению к военнопленным. Ключевые слова: Интернирование японских военнопленных, репатриация японских военнопленных, Дальний Восток России, Хабаровский международный трибунал, Победа над Японией, Организация военных лагерей, японские военные преступники, проблема военного плена, Договоры по военнопленным, современное решение проблемы.
\end{abstract}

Abstract: The subject of this research is the regime of war imprisonment and the relations of the Japanese prisoners of war with the authorities of the USSR in the period from September of 1945 to December of 1956, to which the troops of the Kwantung Army were subjected after the World War II. The presence of Japanese prisoners of war in the Far East of the USSR during the period in question is one of the key facets of the comprehensive study of the issue of foreign POW's in the Far East of Russia in the XX century. Referring to this topic on the 70th anniversary of the USSR's victory over the militarist Japan is supported by the introduction of new documents and materials on this topic that was not previously available to the researchers. The scientific novelty is substantiated by the systemic research of the issue of the POW'S in the Far East of the USSR, and also consists in the introduction of new documents and materials on this topic. The author investigates the international legal aspects of the war imprisonment in the Far East, and determines the specificity of the USSR's policy with regards to prisoners of war.

Keywords: Internment of Japanese POW's, Repatriation of Japanese POW's, Russian Far East, Khabarovsk International Tribunal, Victory over Japan, Organization of war camps, Japanese war criminals, War imprisonment, Treaties on prisoners of war, Modern solution.

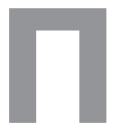

оражение Японии во Второй мировой войне привело к распаду всей японской колониальной империи на Дальнем Востоке и оккупации территории японского государства американскими и английскими войсками. Главнокомандующим союзными оккупационными войсками Японии был назначен командующий вооруженными силами США на Тихом Океане Д. Макартур. Поскольку поверженная в войне Япония не могла на равных со странами-союзницами решать многие вопросы внутренней и внешней политики страны, в том числе и вопросы репатриации своих бывших военнослужащих, эту миссию на время оккупации Японии осуществлял Контрольный Совет по Японии, co- стоявший из представителей четырех держав (СССР, США, Великобритании и Китая), а также Союзный Совет для Японии, в состав которого вошли 4 представителя (по одному из США, СССР и Китая, кроме того, делегат, представлявший одновременно Англию, Австралию, Новую Зеландию и Индию).

«Безусловно, послевоенная Япония не имеет права голоса в международных делах, - писала в 1949 г. газета «Асахи», - но по положению Потсдамской декларации 1945 г. Япония имеет право ... просить как можно скорее репатриировать своих граждан из плена. Это и есть желание японского народа» [1].

Статья 9 Потсдамской декларации 1945 г. гласит, что «японские военные силы после полного их разору- 
жения могут возвращаться на родину и вести мирную трудовую жизнь» [2]. Руководствуясь этой статьей, японское правительство совместно с международными общественными организациями начало широкую многоплановую кампанию по возвращению соотечественников из плена. Прежде всего, это касалось японцев, не репатриированных длительное время из CCCP, поскольку пленные, попавшие в другие страны, были возвращены Японии сразу же после окончания военных действий.

Переговоры о возвращении из советского плена велись на уровне глав правительств заинтересованных государств и ООН. Немаловажную роль в ускорении репатриации японцев играла организация Международного Красного Креста. Кроме того, большую работу по возвращению соотечественников проводил японский парламент, общественные организации Японии и представители семей военнопленных.

19 декабря 1946 г. между Верховным главнокомандующим союзными войсками Японии Д. Макартуром и советским представителем в Союзном Совете для Японии К. Деревянко было подписано официальное соглашение о военнопленных. По этому соглашению Советский Союз обязался с мая 1947 г. репатриировать в Японию не менее 50 тыс. японцев ежемесячно, включая зимнее время. Для этого Д. Макартур совместно с организацией Международного Красного Креста представил России пассажирские суда и ледоколы. Однако за 1946-1949 гг. из СССР в Японию было репатриировано только 150 тыс. чел. [3]. По сообщению штаба Макартура, обще число нерепатриированных из СССР военнослужащих составило к 1949 г. 326617 чел. [4].

«Это означает, что советские власти не выполнили установленные нормы репатриации японцев, - писал К. Макартур в письме к К. Деревянко. - Кроме того, советские власти отказались предъявлять статистические данные, касающиеся числа японцев, находящихся в Советском Союзе. И на сегодняшний день штаб не имеет совершенно никаких официальных сведений относительно здравоохранения, жизненных условий, фамилий, количества и местонахождения японцев в Советском Союзе» [5].

Письмо К. Макартура к К. Деревянко было опубликовано всеми японскими газетами. В ответ, как отмечали токийские журналисты, представитель советской миссии заявил, что ему необходимо время на ознакомление с обвинениями американцев. Однако ответа на поставленные Д. Макартуром вопросы так и не последовало [6].

В январе 1950 г. правительство США направило Ноту протеста Сталину, в которой в очередной раз потребовало разъяснений о судьбе японских плен- ных. США обвинили СССР в нарушении 9 статьи Потсдамской декларации 1945 г., законов Женевской конвенции 1929 г. об основных правах и свободах военнопленных. Аналогичное заявление передал госсекретарь США Д. Ачесон советскому послу в Вашингтоне. В своем заявлении правительство США настаивало на том, чтобы Москва разрешила Международной Организации Красного Креста провести хотя бы частичное расследование жизни японских пленных в СССР. Это, по мнению Д. Ачесона, могло стать единственным средством урегулирования вопроса по военнопленным.

Кроме того, американское правительство выразило беспокойство по поводу слишком большого расхождения в подсчетах числа пленных СССР и Японией. Разница составляла 376929 чел. [7]. «Расхождение является чрезмерно большим, и оно не может быть отнесено за счет ошибки в подсчетах или просмотра», - отмечал Д. Ачесон в обращении к советскому послу. Далее им было высказано предположение, что «большое число японцев продолжает находиться в лагерях, контролируемых Советами, и смертность среди них чрезвычайно высока» [8].

Поскольку представители советской миссии в Японии неоднократно и в категоричной форме отвергали все предложения, касавшиеся репатриации японцев из СССР, национальное собрание Союзного Совета решило обратиться с просьбой о посредничестве к премьер-министру Индии Д. Неру. Обращение к главе индийского правительства было вызвано его дружескими связями со Сталиным и надеждой на то, что нейтральное правительство Индии сможет повлиять на ускорение репатриации японских пленных из СССР. Однако обращение Д. Неру к Сталину также осталось без ответа [9].

В ноябре 1950 г. Генеральная ассамблея ООН в Женеве и комиссия по правам человека приняли на рассмотрение вопрос об ускорении репатриации пленных японцев из СССР. В ООН был создан специальный комитет по вопросам военнопленных. Кроме представителей Японии в него вошли граждане Америки, Великобритании, Германии, СССР, Италии, Голландии, Австралии. На первом заседании комитета представители Японии вновь потребовали от СССР показать им в кратчайшие сроки официальные данные о численности японцев, оставшихся в плену, о количестве умерших. Но представитель Советского Союза, сославшись на отсутствие информации, вновь ушел от ответа [10].

В июне 1951 г. был утвержден состав Международной комиссии ООН, в обязанности которой входил сбор информации о нерепатриированных из 
СССР японских пленных и оказание помощи в их отправке на родину [11]. В 1952 г. на специальном заседании ООН в Женеве рассматривался вопрос о нерепатриированных японцах, задерживаемых в СССР в качестве пленных. Здесь в очередной раз прозвучало обращение к мировой общественности: помогите вернуть оставшихся пленных японцев домой [12].

Министерство иностранных дел и Национальный парламент Японии также делали все возможное для скорейшего возвращения соотечественников на родину. В 1946 г. в МИДе Японии был создан отдел расследования проблем нерепатриированных. Здесь с помощью родственников собирали подробные данные о военнопленных, систематизировали сведения очевидцев, чтобы впоследствии составить примерную картину жизни японцев в советском плену, определить хотя бы приблизительное число соотечественников, находившихся в России.

В парламенте Японии с 1946 г. действовала специальная комиссия по делам реабилитированных соотечественников. Эта комиссия занималась расследованием роли Коммунистической партии Японии в деле задержки репатриантов. Ее члены допрашивали свидетелей нашумевшего «дела Токуда», выносили заключительное обвинение Генеральному секретарю КПЯ К. Токуда в тайном сговоре со Сталиным, требовали его отстранения от политической деятельности, что впоследствии и было выполнено.

Федерация помощи японским гражданам, созданная при японском парламенте, неоднократно принимала иностранных корреспондентов для обсуждения вопроса о возможных путях ускорения репатриации. При парламенте Японии был создан Контрольный Совет, в обязанности которого входила публикация подробных отчетов о жизни военнопленных в России, написанных на основе бесед с бывшими пленными.

Эти отчеты служили основной информацией для работы Союзного и национального правительств. В частности, отчет Контрольного Совета Японии, опубликованный в феврале 1950 г., назывался «Смерть и жизнь японских военнопленных в лагерях Советского Союза». В отчете содержались статистические данные, фотоснимки и несколько разделов, касавшихся взаимоотношений советских граждан с пленными японцами.

Первый раздел назывался «Действительность о смерти в советских лагерях военнопленных» и был посвящен разночтениям в цифровых данных о репатриантах в японских и советских источниках. Второй раздел исследовал питание и уровень медицинского обслуживания пленных. В третьем разделе на основе бесед с вернувшимися шел разговор о реквизите сил японцев в советских лагерях [13].
Все вышеизложенное приводит к выводу о том, что в конце 40-х гг. японцы были хорошо осведомлены о жизни своих соотечественников в советском плену, хотя и не представляли истинных масштабов национальной трагедии.

Помимо международных и государственных организаций большую роль в ускорении репатриации играла общественность Японии. В конце 40-х - начале 50-х гг. в стране насчитывалось более 100 общественных организаций, занимавшихся сбором сведений о жизни соотечественников в России [14]. Среди них «Всеяпонская лига ускорения репатриации». Члены этой лиги (родственники военнопленных) пытались вести переговоры с советским правительством путем пересылки писем и телеграмм в Кремль.

Существовал также «Японский комитет по делам Сибири», в который входили родственники нерепатриированных. Они систематически организовывали митинги и демонстрации в поддержку пленных. В резолюции к советскому правительству «японский комитет» предъявлял следующие требования:

- увеличение пайковых норм военнопленным;

- завершение репатриации японских граждан к октябрю 1948 г.;

- материальная помощь семьям еще не репатриированных военнослужащих;

- публикация имен японских граждан, находившихся в СССР [15].

«Всеяпонская Федерация по ускорению репатриации соотечественников также пыталась ускорить возвращение японцев на родную землю с помощью митингов и забастовок родственников военнопленных. В сентябре 1948 г. Федерация организовала в центральной части Токио серию массовых голодных забастовок членов семей задерживаемых в России японцев. Общее число участвоваших в этой акции составило 500 тыс. чел. [16].

Неоднократно организовывала голодные забастовки родственников военнопленных «Ассоциация содействия репатриации находящихся за рубежом японцев». Один из многочисленных митингов протеста, устроенных этой ассоциацией, проходил на центральной площади Токио, напротив императорского дворца. В знак протеста против медлительности советских властей 2600 членов семей военнопленных одновременно начали голодную забастовку в Буддийском храме Токио. Они заявили, что будут продолжать голодовку до тех пор, пока не получат удовлетворительного ответа от японского правительства на их петицию о немедленной репатриации соотечественников из России [17].

Массовые митинги родственников проводил по всей Японии «Национальный совет по ускорению 
репатриации соотечественников из-за границы». В июне 1951 г. на митинге в Токио, организованном Национальном советом, насчитывалось 2 тыс. родственников военнопленных, прибывших со всех концов страны [18]. Юридической основой своей деятельности Национальный совет считал 9 статью Потсдамской конференции1945 г. и неоднократно ходатайствовал перед японским правительством о включении в будущий мирный договор между Японией и Россией пункта о правах военнопленных и сроках репатриации [19].

В период с 1946 по 1950 гг. по Японии периодически прокатывались волны митингов и забастовок в защиту соотечественников, организаторами которых становились женщины - жены, сестры, матери военнопленных.

Так, в конце 40-х гг. женами военнопленных было организовано массовое движение «Движение братства и любви», состоявшее исключительно из женщин и детей. 11 ноября 1949 г. это движение развернуло по всей Японии кампанию сбора подписей в защиту пленных соотечественников. Позднее от этого движения было отобрано 35 делегаток, которые устроили перед зданием советского посольства в Токио сидячую забастовку с первоначальным требованием: быть допущенными к начальнику советской миссии в Японии К. Деревянко. Однако К. Деревянко отказался выйти к бастующим женщинам [20].

15 декабря 1949 г. женщины и дети, чьи главы семей не вернулись из России, вновь осадили здание советского посольства в Токио. Они требовали продолжения репатриации в зимнее время, обнародования фамилий тех, кто умер в плену и кто был задержан в СССР в качестве военных преступников. Однако ворота посольства оказались запертыми на том основании, что демонстрация женщин и детей Японии является антисоветской. Впоследствии один из чиновников посольства принял представителей «Движения братства и любви», но их вопросы вновь остались без ответа. Встреча, по сообщению токийских журналистов, закончилась тем, что солдаты, стоявшие на страже посольских ворот, вытолкали родственников военнопленных за двери [21].

Массовые митинги японцев за ускорение репатриации часто проходили на дворцовой площади Токио. Более 5 тыс. японцев собрались здесь 29 апреля 1949 г. по инициативе группы «Движение за счастье всех людей». Демонстранты пошли к советскому посольству с национальными флагами, а плакаты в их руках изображали, по словам японских журналистов, «мерзнущих, голодных и больных японцев, перетаскивающих тяжелые грузы в советских лагерях» [22]. «И это в то время, - гласили надписи под рисунками, когда по ту сторону Японского моря их со слезами умоляют о возвращении» [23].

В 1951 г. в Японии состоялся продолжительный национальный съезд японских семей, главы которых находились в советском плену. Многотысячный съезд проходил в помещении храма «Содсюдзи» (г. Иокогама). На съезде были впервые обнародованы несколько сотен имен японских военнопленных, погибших в России. Их имена были опубликованы в специальной «Белой книги репатриации». Представители съезда, не зная истинных цифр потерь военнопленных, были поражены количеством погибших и, по словам японских журналистов, обступили вице-министра по иностранным делам Кусаба, присутствовавшего на съезде, и требовали от него подробной информации о причинах смерти соотечественников [24].

Отличительными особенностями движения японцев за возвращение соотечественников из плена были, с одной стороны, массовость, с другой, - яркое проявление личной инициативы. В частности, гражданин Японии Наоки Хосино, брат военнопленного, объявленного в СССР военным преступником, провел 40-дневную голодовку в знак протеста против задержки репатриации. Более того, он собрал 8 млн. подписей сограждан под петицией об ускорении возвращения соотечественников из плена.

За время своей голодовки Хосино пил только воду. В день ее окончания он, по словам японских корреспондентов, «белый как простыня и тонкий как спичка», сказал о своем желании собрать 10 млн. подписей под петицией об ускорении возвращения соотечественников из плена, которую намерен предъявить советской миссии в Токио. Это была уже третья по счету голодовка Хосино. Первые две длились по 20 дней. Впоследствии Наоки Хосино был избран в верхнюю палату парламента, где возглавил группу по ускорению репатриации [25].

Широкий отклик по всей Японии в 1950 г. получила акция 27-летней японской домохозяйки Кейко Икено. Она заявила корреспондентам, что послала 3 телеграммы Сталину с просьбой ускорить репатриацию ее военнопленного супруга. Кейко Икено заявила японским журналистам, что не получила от советского премьера никакого ответа и потому уверенна, что ее обращение к Сталину бесполезно.

Она также заявила, что, хотя русские через ТАСС официально уведомили о репатриации всех пленных японцев, за исключением военных преступников, ее 35-летний муж, раннее работавший в Маньчжурской электрокомпании, в Японию не вернулся, хотя и не был военным преступником, остался в одном из сибирских лагерей. 
Одновременно с К. Икено 30 -летняя учительница Судзуко Ямада из префектуры Якуи сообщила, что ее муж, также не являвшийся военным преступником, до сих пор находится в русском плену.

Поскольку демонстрации и забастовки родственников приняли в Японии массовый характер, правительство, опасаясь нарушений общественного порядка, было вынуждено начать антизабастовочную кампанию «За успокоение семейств», члены семей которых находились в советском плену. Такие семьи были на специальном учете комиссии японского парламент, занимавшейся военнопленными, о них проявляли заботу - оказывали моральную и материальную поддержку, осуществляли сбор сведений о пропавших без вести в России [26].

Дольше других в России задержались японцы, признанные военными преступниками и осужденные на Хабаровском судебном процессе 1949 г., а также военнопленные, выступившие в качестве свидетелей на Токийском и Хабаровском международных судебных процессах. Токийский процесс проходил с 3 мая 1946 г. по 12 ноября 1948 г., Хабаровский международный трибунал состоялся 25-30 декабря 1949 г. На обоих процессах использовались свидетельские показания военнопленных, находившихся в дальневосточных лагерях.

Суду международного военного трибунала в г. Токио были преданы 28 бывших государственных, политических и военных деятелей Японии по обвинению в заговоре против мира, т.е. в подготовке, развязывании и ведении агрессивных войн. Среди них был бывший премьер-министр Японии Тодзио Хидэки, бывший военный министр и член правительственного совета, полный генерал Араки Садао, командующий армией в Сингапуре, полный генерал Доихара Кэндзи, депутат парламента Хасимото Кингоро, бывший военный министр и член Верховного совета, полный генерал Хата Сюнроку и другие [27].

На заседании Международного Военного Трибунала для Дальнего Востока в Токио один из 13 крупнейших разделов обвинения был посвящен преступлениям военнослужащих Квантунской армии против пленных на суше и на море. В обвинении указывалось, что японское правительство не ратифицировало и не ввело в действие Женевскую конвенцию от 27 июля 1929 г. о содержании военнопленных. Против ратификации этой конвенции еще задолго до начала Второй мировой войны решительно выступили армия и военно-морской флот Японии, которые считали, что конвенция своей гуманностью противоречит основным положениям военной подготовки японского солдата. Отказ от ратификации этой конвенции был сознательным шагом военных политиков Японии для внушения ее военнослужащим ненависти и презрения к попавшим в плен на поле боя.

Поэтому, начиная с военных действий в Китае и кончая капитуляцией в сентябре 1945 г., убийства, пытки, изнасилования и другие акты жестокости самого бесчеловечного и зверского характера по отношению к военнопленным широко практиковались в японской армии и флоте.

Еще в начале 1946 г. МВД СССР по поручению советского правительства начало поиск предполагаемых свидетелей в лагерях военнопленных, сбор материалов о них и их анализ. Уже в апреле 1946 г. был подготовлен список свидетелей из 77 японцев, находившихся в советском плену. Среди них было 30 генералов, 36 офицеров, 11 гражданских лиц, интернированных в Маньчжурии 1945 г. [28].

Конкретные имена японских военных преступников, уничтожавших десятки тысяч военнопленных различных национальностей, прозвучали на Хабаровском международном процессе по делу бывших военнослужащих Квантунской армии, обвиняемых в подготовке и применении бактериологического оружия. Этот процесс, проходивший с 25 по 30 декабря 1949 г. в Хабаровске, явился логическим продолжением заседаний Международного Военного Трибунала в Токио».

Дело рассматривалось в открытом судебном заседании Военным трибуналом Приморского военного округа. В судебных заседаниях показания давали свидетели - бывшие военнослужащие Квантунской армии, ставшие военнопленными на территории советского Дальнего Востока, а также бывшие служащие жандармерии, вольнонаемные работники, интернированные в СССР: начальник отдела кадров Квантунской армии, полковник Тамура Тадаси (взят в плен 1 сентября 1945 г. в г. Чаньчуне), санитар отряда №731 Фуруити Есио (взят в плен 17 августа 1945 г.), начальник жандармского управлеия г. Цзямусы полковник Татибана Такэо, фельдфебель Куракадзу Сатору (был взят в плен в августе 1945 г. и 12 сентября через станцию Пограничная Приморского края отправлен в СССР), офицер-стажер интендантской службы подпоручик Сэгоси Кэнити, лаборант отряда №731 Косукэ, сотрудник отряда №731 Одзэки Сигэо, работник канцелярии отряда №731 Сайто Масатару, вольнонаемный Кувабара Акира, рядовой Хатаки Акира, военнослужащие Квантунской армии Сакурасита Киеси, Фукудзими Мицуеси, Минэой Каяси, Канадзава Кадзухиса, Сэгоси Кенити и др. [29].

Показания свидетелей на процессе в г. Хабаровске подтвердили, что в целях массового истребления войск и мирного населения Японией еще с 1931 г. 
предусматривалось применение в войне бактериологического оружия. С этой целью на территории захваченной японцами Маньчжурии были развернуты 2 крупных бактериологических учреждения, рассчитанных не только на изыскание способов ведения бактериологической войны, но и на производство бактериологического оружия в размерах, достаточных для полного снабжения японской армии.

Как было установлено на процессе, бактериологическое оружие рассматривалось Японией как эффективное средство ведения войны. Японским генштабом были утверждены 3 основных метода применения бактерий для целей войны: распыление бактерий с боевых самолетов, сбрасывание с самолетов специальных бактериологических бомб и наземное заражение населенных пунктов, водоемов, пастбищ и т.д. по методу бактериологических диверсий [30].

Как было установлено в ходе следствия, только в одном отряде №731 ежедневно истреблялось не менее 600 военнопленных, а с 1940 г. по день капитуляции японской армии 2 сентября 1945 г. было умерщвлено не менее 3 тыс. чел. [31].

На Хабаровском процессе в декабре 1949 г. судом военного трибунала по статье 2-й Указом Президиума Верховного Совета СССР от 19 апреля 1943 г. были осуждены 12 человек - участников подготовки и применения бактериологического оружия: главнокомандующий Квантунской армии генерал Ямада Отодзо; насчальник санитарного управления Квантунской армии Кадзицука Рюдзи; начальник ветеринарного управления Квантунской армии генерал-лейтенант Такахаси Такацу; начальник производственного отдела отряда №731 генерал-майор Кавастима Киеси. На 18 лет лагерей был осужден начальник филиала №673 отряда №731 в г. Суньу подполковник Ниси Тосихидэ; на 20 лет - начальник отделения отряда №731 майор Карасава Томио; на 12 лет - начальник филиала отряда №731 майор Оноуэ Масао; на 20 лет лагерей - командир отрядов «Нами» и «Эй» генерал-майор медицинской службы Сато Сюндзи; на сроки от 3 до 15 лет были осуждены поручик Кирадзакура Дзэнсаку, старший унтер-офицер Митомо Кадзуо, ефрейтор Кикути Норимицу, санитар-лаборант Курусима Юдзи. Виновность их в истязании и гибели почти 3 тыс. человек, из которых около 40 - русские жители Харбина и его окрестностей, была неоспоримо доказана [32].

Прокуратура Приморского военного округа, которая выносила обвинение японским преступникам, дала им возможность защищаться на суде. Защитниками подсудимых были представители Московской, Хабаровской и Приморской коллегии адвокатов. Так, генерала Ямада Отодзо защищал член
Московской коллегии адвокатов Н.П. Белов, майора медицинской службы Карасава и майора медицинской службы Оноуэ - председатель Хабаровской коллегии адвокатов В.И. Лукьянцев; старшего унтер-офицера Митомо, ефрейтора Кикучи и лаборанта Курусима - председатель Приморской коллегии адвокатов Г.К. Прокопенко. «...Я не собираюсь защищать те поистине исключительные по своей тяжести преступления, о которых так подробно говорил в своей речи государственный обвинитель, - сказал о своем подзащитном - главнокомандующем Квантунской армией генерале Ямада - адвокат Н.П. Белов. - Я защищаю уже совсем немолодого человека - подсудимого Ямада, принимавшего в силу роковых для него причин и обстоятельств определенное участие в попрании законов и обычаев войны, в совершении преступлений против человечества. Установлено по делу, что Ямада родился, рос, формировался в такой обстановке и в таких условиях, в которых он стал олицетворением такой военной дисциплинированности, которая являлась... психическим автоматизмом. Ямада поэтому достоин не только осуждения, но и сожаления. Подсудимый нашел в себе силу и мужество... полностью признать свою вину [33].

О смягчении приговоров своим подзащитным просили и другие советские адвокаты, видя за преступлениями многих японских военачальников привычку подчиняться военному приказу, каким бы бесчеловечным он ни являлся.

Глубокое всестороннее изучение личности каждого подсудимого на Хабаровском процессе, гуманное отношение советского суда к японским военным преступникам не могло остаться незамеченным как самими японцами, так и всей мировой общественностью.

Во время подготовки Хабаровского процесса многие обвиняемые японцы, как и свидетели обвинения, находились в специальных лагерях военнопленных. Так, в Хабаровском спецлагере №50 содержался японский генералитет. Здесь находилось 37 бывших генералов армии и адмиралов флота. В 1950 г. 32 генерала - свидетеля обвинения были репатриированы в Японию [34].

К апрелю 1950 г. в Советском Союзе находилось 2458 японских военнослужащих различных рангов и званий, обвиняемых в военных преступлениях. Многие из них были осуждены на срок от 15 до 25 лет. Однако Указом Президиума Верховного Совета СССР «Об амнистии японских граждан, осужденных в Советском Союзе» от 13 декабря 1956 г. в связи с прекращением состояния войны и установлением мирных отношений между СССР и Японией все осужденные японцы были освобождены из мест заключения и возвращены на родину [35]. 
Вместе с тем военными судами в СССР было осуждено немало солдат и офицеров Квантунской армии, захваченных советскими частями на территории Маньчжурии в августе 1945 г. Большинство военнопленных, оказавшись в СССР, были незаконно осуждены по 58-й статье УК РСФСР «за шпионаж и оказание помощи международной буржуазии» на сроки от 10 до 25 лет [36]. Среди осужденных были военные переводчики, делопроизводители, преподаватели русского языка, полицейские, заведующие боевыми и продовольственными складами, бухгалтеры. Само возбуждение и последующее рассмотрение этих дел с признанием японских граждан военнослужащих виновными в шпионаже и оказании мировой буржуазии являлись незаконными с самого начала и противоречили нормам международного права. Фактически этих военнослужащих советские суды обвиняли в добросовестном выполнении своих служебных обязанностей в период несения военной службы.

В 90-е гг. Военный суд Краснознаменного Дальневосточного военного округа (г. Хабаровск) и военный трибунал Тихоокеанского флота (г. Владивосток) провели большую работу по реабилитации незаконно осужденных японцев. В соответствии с законом РСФСР от 18 октября 1991 г. «О реабилитации жертв политических репрессий военный трибунал Тихоокеанского флота за 1991-1992 гг. 16 незаконно осужденных японских военнослужащих, военный суд Краснознаменного Дальневосточного военного округа отменил приговоры 26 японцам [37].

Начиная с первых послевоенных лет, японская и международная общественность ждала от СССР официальной правовой оценки самого факта перемещения огромной массы японских военнослужащих Квантунской армии на советскую территорию уже после окончания боевых действия и капитуляции Японии. Очевидно, что правовой статус японских военнопленных, вывезенных на территорию СССР после окончания войны на Тихом океане, определялся участием России в Гаагских конвенциях 1899 и 1907 гг., в частности, приложением к VI Гаагской конвенции 1907 г. В нем говорилось, что воюющее государство, во власть которого попали пленные, имеет право привлекать их к подходящим работам, но с другой стороны, обязано давать им содержание, соответствующее их чину. Одновременно в том документе отмечалось, что «По заключению мира военнопленные должны быть отпущены домой в самый короткий срок» и «с ними надлежит обращаться человеколюбиво» [38].

Статус военнопленных определялся и внутригосударственными правовыми актами СССР, такими, как
«Положение о военнопленных», утвержденное СНК СССР 1 июля 1941 г. Оно основывалось как на ратифицированных СССР международных соглашениях, так и на обычных нормах международного права, а также на тех актах, которые касались советских граждан (вопросов труда, уголовных преступлений и т.д.). В то же время СССР не был участником Женевской конвенции «Об обращении с военнопленными» 1929 г., хотя и заявлял о своей приверженности принципам гуманизма и международного права [39].

В отношении военнопленных японцев на территории СССР применял положения международного права о том, что страна, держащая в плену, может использовать военнопленных в качестве рабочей силы с учетом их возраста, пола, звания, физических возможностей. Соблюдение законов об охране труда, правил техники безопасности при использовании труда японских военнопленных должно было осуществляться в соответствии с практикой, принятой в СССР по отношению к заключенным и военнопленным.

Ущерб, полученный военнопленными во время работы по вине администрации, в соответствии с советским законодательством должен был возмещаться администрацией предприятия. Однако советскояпонское соглашение 1956 г. формулировало отказ от взаимных претензий. Таким образом, если ущерб военнопленному не был возмещен советской стороной до 1956 г., обязанности по его возмещению перешли к японскому правительству [40].

Законы международного права гласят, что военнопленный за свой труд может получать заработную плату как наличными, так и с зачислением на лицевой счет. Этого сделано не было. Японские военнопленные деньги в СССР за свой труд не получали.

В соответствии с существующей практикой держава, у которой находился военнопленный, обязана была выдать ему удостоверение о труде. Так поступили практически все государства, кроме СССР, где находились японские военнопленные (США, Великобритания, Новая Зеландия, Австралия, Франция). Правительство Японии признало эти документы в качестве основания для выплаты компенсации военнопленным. В этих документах были указаны размеры заработной платы военнопленных, а также сумма, израсходованная на их содержание.

Отсутствие документа о труде бывшим японским военнопленным прибывшим из СССР, явилось поводом для японского правительства отказать им в денежной компенсации. Крупнейшая в Японии общественная организация бывших военнопленных - Всеяпонская ассоциация бывших военнопленных - считала отказ японского правительства выдать денежную компенса- 
цию военнопленным, вернувшимся из России, попыткой создать очаг холодной войны в японо-российских отношениях. «На основе Женевской конвенции, касающейся вопросов военнопленных, денежная компенсация за труд в плену должна осуществлять страна, подданными которой они являются, т.е. Япония. Такая компенсация была предоставлена военнопленными, вернувшимися из США, Англии на основании документов о труде, выданных этими странами. Что же касается бывших японских военнопленных, вернувшихся из СССР, японское правительство отказывает им в выдаче компенсации, ссылаясь на то, что советское правительство не выдало соответствующие удостоверения. Однако, по мнению Международного Красного Креста, компенсация должна быть предоставлена даже без этого документа по существующей аналогии» [41].

В 1992 г. правительство России выдало 100 справок о труде бывшим японским солдатам и офицерам. К апрелю 1993 г. было выдано уже 100 тыс. таких справок. По настоящее время во Всеяпонскую ассоциацию бывших военнопленных поступают новые заявления японцев о выдаче им справок о труде в СССР. Но до окончательного решения проблемы еще далеко.

Поместив в сибирские и дальневосточные лагеря многотысячную армию японских военнопленных и заставив их работать в различных отраслях народного хозяйства, СССР нарушил многие пункты междуна- родных соглашений, касающиеся правил обращения с военнопленными, их содержания и обеспечения, репатриации. Кроме этого, Советский Союз практически игнорировал требования международной общественности приоткрыть завесу тайны над японским интернированием, предоставить реальные цифры по количеству находившихся в плену японцев. Полное отсутствие гласности, казалось бы, гарантировало нераспространение информации о военнопленных как внутри страны, так и за рубежом. Однако японское правительство и американские оккупационные власти стали проявлять беспокойство в связи с фактом исчезновения в СССР сотен тысяч японцев начиная с 1946 г. К этому официальные органы Японии и Америки подталкивали массовые движения общественных организаций, образованных, прежде всего, родственниками военнопленных, находившихся в СССР.

Вместе с тем среди военнопленных находились и лица, совершавшие преступления против мира (планирование, подготовка, развязывание войны или ведение войны в нарушение международных договоров, соглашений или заверений или участие в заговоре, направленном на осуществление вышеизложенного; нарушение законов или обычаев войны - убийства, истязания или увод в рабство, или для других целей гражданского населения оккупированной территории; преступления против человечности.

\section{Библиография:}

1. Архив военного трибунала Краснознаменного Тихоокеанского флота

2. Архив оперативного отдела Управления внутренних дел Приморского края, г. Владивосток

3. Архив военно-исторического музея Дальневосточного Военного округа, г. Хабаровск

4. Архив военного суда Краснознаменного Дальневосточного военного округа, г. Хабаровск.

5. Государственный архив Хабаровского края (далее ГАХК), г. Хабаровск. Ф.Р. ᄀ-1036. Хабаровское отделение ТАСС. Оп. 1. Д. 438, 439, 440, 441, 447, 470, 472, 476, 479, 504; Оп. 4. Д. 1.

6. Документы внешней политики СССР Т. 1. [ Текст] / Ред. А.А. Громыко.-М.: Госполитиздат, 1957.-771 с.

7. Кузнецов, С. И. Проблема военнопленных в российско-японских отношениях после второй мировой войны. /С.И. Кузнецов.-Иркутск.: Иркут. гос. ун-т, 1994.-190 с.

8. Рагинский, М.Ю. Милитаристы на скамье подсудимых. По материалам Токийского и Хабаровского процессов. Монография. / М.Ю. Рагинский. - М.: Издательство Юридическая литература, 1985. - 365 с.

9. Бюллетень Японской Ассоциации бывших военнопленных. - Цуруока, 1988, 1989, 1991

10. Владивосток. 1992. 19 июня

11. Япония: Ежегодник. - М., 1973

12. Правда. - М., 1949, 1950, 1953, 1955.

13. Красная Звезда. - М., 1950, 1953, 1955, 1992.

\section{References (transliterated):}

1. Kuznetsov, S. I. Problema voennoplennykh v rossiisko-yaponskikh otnosheniyakh posle vtoroi mirovoi voiny. /C.I. Kuznetsov.Irkutsk.: Irkut. gos. un-t, 1994.-190 s.

2. Raginskii, M.Yu. Militaristy na skam'e podsudimykh. Po materialam Tokiiskogo i Khabarovskogo protsessov. Monografiya. / M.Yu. Raginskii. - M.: Izdatel'stvo Yuridicheskaya literatura, 1985. - 365 s. 